\title{
Mortality differences between migrants and Italians residing in Rome before, during, and in the aftermath of the great recession. A longitudinal cohort study from 2001 to 2015
}

Eleonora Trappolini ${ }^{1}$, Claudia Marino ${ }^{2}$, Nera Agabiti $^{2 *}$, Cristina Giudici $^{3}$, Marina Davoli $^{2}$ and Laura Cacciani ${ }^{2}$

\begin{abstract}
Background: In Europe, one of the most consistent findings is that of migrant mortality advantage in high-income countries. Furthermore, the literature shows that economic shocks, which bring worse health outcomes, can severely affect the most disadvantaged individuals. We analyse differences and changes in all-cause mortality between Italians and migrants residing in Rome before, during, and in the aftermath of the Great Recession (20012015) by birth-cohort.

Methods: The analysis is a longitudinal open cohort study. Mortality data come from the Register of the Causes of Death $(58,637$ deaths) and the population denominator $(n=2,454,410)$ comes from the Municipal Register of Rome. By comparing three time-periods (2001-2005, 2006-2010, and 2011-2015), we analyse all-cause mortality of Rome residents born, respectively, in the intervals 1937-1976, 1942-1981, 1947-1986 (aged 25-64 years at entry into observation). Computing birth-cohort-specific death rates and applying parametric survival models with age as the time-scale, we compare mortality differences between migrants and Italians by gender, area of origin, and time-period.

Results: Overall, we find a lower risk of dying for migrants than Italians regardless of gender (Women: HR $=0.61,95 \%$ Cl 0.56-0.66; Men: HR= 0.49, 95\% Cl 0.45-0.53), and a lower death risk over time for the total population. Nevertheless, such a pattern changes according to gender and migrants' area of origin.

Conclusion: Given the relevance of international migrations in Europe, studying migrants' health has proved increasingly important. The deterioration in migrant health and the gradual weakening of migrants' mortality advantage is likely to become a public health issue with important consequences for the healthcare system of all European countries.
\end{abstract}

Keywords: Mortality, Migrants, Longitudinal study, Dynamic cohort, Great recession, Italy

\footnotetext{
* Correspondence: n.agabiti@deplazio.it

${ }^{2}$ Department of Epidemiology, Lazio Regional Health Service, Via Cristoforo Colombo, 112, 00147 Rome, Italy

Full list of author information is available at the end of the article
}

(c) The Author(s). 2021 Open Access This article is licensed under a Creative Commons Attribution 4.0 International License, which permits use, sharing, adaptation, distribution and reproduction in any medium or format, as long as you give appropriate credit to the original author(s) and the source, provide a link to the Creative Commons licence, and indicate if changes were made. The images or other third party material in this article are included in the article's Creative Commons licence, unless indicated otherwise in a credit line to the material. If material is not included in the article's Creative Commons licence and your intended use is not permitted by statutory regulation or exceeds the permitted use, you will need to obtain permission directly from the copyright holder. To view a copy of this licence, visit http://creativecommons.org/licenses/by/4.0/. The Creative Commons Public Domain Dedication waiver (http://creativecommons.org/publicdomain/zero/1.0/) applies to the data made available in this article, unless otherwise stated in a credit line to the data. 


\section{Background}

In the past 50 years, health improvements have been registered all over Europe. However, there are still many examples of mortality differences by social group $[1,2]$, by gender $[3,4]$, and for migrants compared with host populations [5-7].

The 2008 Great Recession, which was the result of the financial crisis that started in late 2007 in the United States, was particularly severe in Southern Europe, where there were big increases in unemployment, as well as generalized banking problems, large public and private debts, and austerity policies. In Italy, the negative growth registered in the GDP has been stronger compared to other Eurozone countries, and when the second phase of the crisis started, known as the European sovereign debt crisis, the Country again entered into recession starting from July 2011 [8], continuing to experience negative economic growth until the whole 2014 [9].

Among other things, the recession caused serious financial issues for public services, including the healthcare sector. Reductions in healthcare spending compromised the quality of services provided, leading to a deterioration in health outcomes [10]. Moreover, reductions in household budgets due to unemployment, or reductions in pensions and wages, decrease the individual's ability to adopt healthy lifestyles and pay for healthcare, again leading to a deterioration in health. This deterioration seems to be particularly evident in countries with weak social protection [11].

In Europe, the impact of the Great Recession on health remains controversial and empirical studies on health and mortality differ in their findings [12-18]. Counterintuitively, at the population-level, many authors have reported a pro-cyclical effect on general mortality, known as the "Thomas effect", which means mortality goes up with economic expansions and down with contractions [19-28]. Conversely, at the individual-level, some scholars have registered quite the contrary. Whatever the health indicator used, the effect of economic downturns is always associated with a deterioration in health outcomes [29, 30]. In Italy, Egidi and Demuru (2016) [31] claimed that the Great Recession caused a slowdown in mortality improvements.

Regarding differences in mortality between natives and migrants, one consistent finding in the literature relates to the migrant mortality advantage in high-income countries. This phenomenon implies that migrants have lower mortality than natives or at least lower than might be expected given their double disadvantage, as migrants and their relative poverty [5-7, 32-36].

Although in Italy the number of migrants has constantly increased, reaching a peak of more than 5.2 million in 2019 (8.7\% of the total population) [37], there are few studies on migrant mortality. There are a handful of cross-sectional works [38-40] and only two longitudinal studies $[41,42]$. As far as we know there are no studies on mortality differences between migrants and nonmigrants by birth-cohort before and during the Great Recession.

Our study contributes to the Italian literature about migrants' mortality which is still poor. It does so by providing additional evidence on mortality differences between migrants and Italians during the economic crisis. Using a longitudinal approach based on a dynamic population cohort, the aim of this study is twofold. First, it analyses all-cause mortality differences between Italians and migrants residing in Rome before and during the Great Recession (2001-2015) by birth-cohort. Second, by comparing three different five-year time-periods (2001-2005, 2006-2010, and 2011-2015) the study explores whether, comparing mortality among migrants with mortality among the Italian-born population, hazard ratios differ in the time-periods analysed.

Given the mortality advantage observed in highincome European countries among migrants, our first hypothesis is that since, in Italy, the migration phenomenon is relatively recent compared to other European countries, the healthy migrant effect will still be evident. Migrants may benefit, then, from a survival advantage. The analysis over a period of 15 years allows to assess changes in mortality patterns by migrant status. We expect to find a decrease in mortality level for Italians, following the pattern of improvement observed in the last years. We also expect to find a decrease in the mortality advantage for migrants because both of their low socio-economic condition, which persists through the whole period under analysis; and the increase in migrants' length of stay, associated with negative acculturation and assimilation processes, compounded by the economic downturn. Finally, we hypothesise that the effect of the economic downturn on mortality will be mostly captured during the third period, which combined the effects of the first and second phases of the crisis.

\section{Methods}

\section{The study setting}

The study was set in Rome, the capital of Italy, which is situated in the Lazio region in central Italy. In 2019, the city counts 2.8 million residents, and it is the first Italian city by number of migrants (more than 340,000). In the last two decades, the city was characterised by a rapid increase in the migrant population, which passed from $3.9 \%$ of the total residents in 2002 to $13.4 \%$ in 2019 [37]. Currently, the largest migrant communities settled in Rome are Romanians and Filipinos, which are femaledominated. Indeed, in Rome female migrants represented $53 \%$ of the total migrants. This aspect may show 
the tendency of the capital to attract female migrants, particularly for domestic jobs [43]. As at the national level, another characteristic of the city is to host a plurality of migrants' country of origin, about 195 different nationalities in 2019 [37], which reflect different cultures, behaviours, and health needs.

\section{Research design and cohort description}

A longitudinal population-based open cohort study was conducted, using data from the Rome Dynamic Longitudinal Study cohort, which is part of the Italian Network of Longitudinal Metropolitan studies (IN-liMeS) [41, 42, 44]. The dynamic cohort is based on the Municipal Register of Rome, which provides individual demographic information (sex, age, birthdate, birthplace, date of registration in the Municipality of Rome, and date of cancellation from the population register) for all who have been resident in Rome from 1st January 2001 to 31st December 2015 (4,143,462 records, which correspond to $3,978,400$ individuals). ${ }^{1}$

Starting from the cohort data, we excluded records that did not have reliable Health Information System code $(43,393$ out of $4,143,462,1.0 \%)$, for a total of $3,935,007$ individuals. For analysis purposes, we identified three time-periods $(2001-2005,2006-2010,2011-$ 2015) allowing for a maximum follow-up of five years in each time-period, and for a maximum of 15 years overall. At the beginning of each time-period, we considered residents in Rome aged 25-64 years. Thus, for the first period we selected those individuals belonging to the birth cohorts from 1937 to 1976 (1,822,603 individuals); for the second time-period those from 1942 to 1981 $(1,842,393$ individuals); and for the third one those from 1947 to 1986 (1,815,152 individuals). Within each timeperiod, entry into the study population can take place for immigration or age ( $\geq 25$ years old). Meanwhile, exit can come about because of emigration, age ( $\geq 65$ years old), death, or the end of the study. Subsequently, we computed person-years at risk from the date of enrolment until death, emigration, or to the end of the follow-up. Combining the three time-periods the final study population is composed of 2,454,410 individuals.

\section{Study variables}

\section{Outcome}

The outcome variable is all-cause mortality, retrieved by linking the cohort data with the register of the causes of death (ReNCaM) using an individual anonymised code. The register contains information about the deaths of all

\footnotetext{
${ }^{1}$ Each row of the cohort dataset is a record that contains individual information from the population register of Rome. In the dynamic cohort, individuals may have multiple records as they can enter as residents in Rome, emigrate and remigrate afterwards.
}

residents in the Lazio region, in which Rome is to be found.

\section{Exposures and control variables}

Migrant status is the exposure variable (migrants vs. Italians). This study defined as migrant all individuals born abroad. For more in-depth analyses we classified migrants according to their area of origin, distinguishing between migrants coming from High Migratory Pressure Countries (HMPC: Central Eastern Europe, Africa, Asia - except for Israel and Japan - and Latin America) and migrants coming from all other countries, i.e. Highly Developed Countries (HDC). Being Italian is the reference category.

The time-period is considered as a potential effect modifier. It takes the value ' 0 ' from $01 / 01 / 2001$ to 31 / $12 / 2005$, ' 1 ' from $01 / 01 / 2006$ to $31 / 12 / 2010$, and ' 2 ' from $01 / 01 / 2011$ to $31 / 12 / 2015$.

Gender is a stratification variable.

\section{Statistical analysis}

In order to analyse differences and changes in mortality between migrants and non-migrants, in the first part of the study, we investigated mortality patterns by timeperiod (2001-2005, 2006-2010, 2011-2015), by considering different birth-cohorts of residents in Rome by gender. Combining death and person-years, we computed birth-cohort-specific death rates by gender, timeperiod, and migrant status.

In the second part of the study, we used a parametric survival model with Gompertz baseline hazard to examine the influence of the area of origin on mortality. In the case of mortality, a Gompertz distribution (which suggests an exponential increase in mortality over age) has been shown to provide a very close fit to adult mortality in western countries [5]. We used age as time-scale as it modifies an individual's risk of dying [45]. For our purposes, death is the failure event. So individuals enter the analysis at their baseline age (left-truncation) and exit at their failure event or censoring age, emigration, or the end of the follow-up.

To test whether the time-period effect on all-cause mortality differs among migrant subgroups we included the interaction between the area of origin and the timeperiod.

The SAS software environment 9.4 was used for data management, and all calculations have been performed using STATA 15.

\section{Results}

We included 2,454,410 individuals who resided in Rome from 2001 to 2015; among them, 19.7\% were migrants $(n=484,421)$, of whom $53.3 \%$ women. Over the study period, we observed 58,637 deaths within 24.6 million 
person-years; among migrants, 3766 deaths $(6.4 \%$ of all deaths) occurred within 3.6 million person-years. The migrant population came mainly from Central Eastern Europe, with an increase from 2.7\% (2001-2005) to 7.1\% (2011-2015), followed by, Asia, Africa, HDC, and Latin America. As in the national context, migrants mitigate the ageing of the Roman population: over the study period the median age among migrants was 39.4 years old vs. 43.1 among Italians. Table 1 shows descriptive statistics of the socio-demographic characteristics included in the analysis of migrant groups and the Italianborn population by the three time-periods separately.

Figure 1 shows birth-cohort-specific death rates (BCSDR) on a log-scale by gender, migrant status, and time-period. Migrants showed lower BCSDR compared with Italians in each time-period. When comparing

Table 1 Demographic characteristics of migrants and Italians residing in Rome, and deaths by time-period

\begin{tabular}{|c|c|c|c|c|c|c|c|c|c|c|c|c|}
\hline & \multicolumn{4}{|c|}{ 2001-2005 } & \multicolumn{4}{|c|}{ 2006-2010 } & \multicolumn{4}{|c|}{ 2011-2015 } \\
\hline & \multicolumn{2}{|c|}{ Italians } & \multicolumn{2}{|c|}{ Migrants } & \multicolumn{2}{|c|}{ Italians } & \multicolumn{2}{|c|}{ Migrants } & \multicolumn{2}{|c|}{ Italians } & \multicolumn{2}{|c|}{ Migrants } \\
\hline & Subjects $^{a}$ & Deaths $^{\mathbf{b}}$ & Subjects & Deaths & Subjects & Deaths & Subjects & Deaths & Subjects & Deaths & Subjects & Deaths \\
\hline \multicolumn{13}{|l|}{ Area of origin } \\
\hline Italy & 86.8 & 95.0 & $-^{c}$ & - & 82.1 & 93.8 & - & - & 78.6 & 91.5 & - & - \\
\hline $\mathrm{HDC}$ & - & - & 2.8 & 1.1 & - & - & 2.9 & 1.1 & - & - & 2.6 & 1.1 \\
\hline HMPC & - & - & 10.4 & 3.9 & - & - & 15.0 & 5.1 & - & - & 18.8 & 7.4 \\
\hline \multicolumn{13}{|l|}{ of which } \\
\hline Africa & - & - & 2.5 & 1.9 & - & - & 2.7 & 1.8 & - & - & 3.2 & 2.0 \\
\hline Latin America & - & - & 2.2 & 0.6 & - & - & 2.7 & 0.7 & - & - & 2.6 & 1.0 \\
\hline Asia & - & - & 3.0 & 0.7 & - & - & 4.1 & 1.2 & - & - & 5.9 & 1.8 \\
\hline Central Eastern Europe & - & - & 2.7 & 0.7 & - & - & 5.5 & 1.4 & - & - & 7.1 & 2.6 \\
\hline \multicolumn{13}{|l|}{ Gender } \\
\hline Women & 44.0 & 35.4 & 7.2 & 2.3 & 41.6 & 36.3 & 9.8 & 2.7 & 40.0 & 36.3 & 11.4 & 3.8 \\
\hline Men & 42.7 & 59.6 & 6.0 & 2.6 & 40.5 & 57.6 & 8.1 & 3.5 & 38.7 & 55.2 & 10.0 & 4.7 \\
\hline \multicolumn{13}{|l|}{ Birth Cohort } \\
\hline 1982-1986 & - & - & - & - & - & - & - & - & 7.3 & 1.1 & 3.2 & 0.3 \\
\hline 1977-1981 & - & - & - & - & 8.3 & 1.8 & 2.9 & 0.2 & 8.6 & 1.8 & 3.7 & 0.5 \\
\hline 1972-1976 & 11.3 & 2.1 & 2.2 & 0.2 & 11.3 & 2.6 & 3.2 & 0.4 & 11.0 & 3.3 & 3.5 & 0.7 \\
\hline 1967-1971 & 12.6 & 3.4 & 2.6 & 0.4 & 12.2 & 4.4 & 3.2 & 0.6 & 11.7 & 6.0 & 3.3 & 0.9 \\
\hline 1962-1966 & 12.9 & 5.0 & 2.4 & 0.4 & 12.4 & 7.1 & 2.7 & 0.8 & 12.0 & 10.6 & 2.7 & 1.1 \\
\hline 1957-1961 & 10.9 & 6.7 & 1.9 & 0.5 & 10.4 & 9.7 & 2.2 & 0.8 & 10.1 & 14.8 & 2.2 & 1.5 \\
\hline 1952-1956 & 9.7 & 9.3 & 1.5 & 0.6 & 9.3 & 14.1 & 1.7 & 1.0 & 9.0 & 21.1 & 1.6 & 1.8 \\
\hline 1947-1951 & 10.0 & 13.9 & 1.1 & 0.7 & 9.4 & 21.8 & 1.2 & 1.2 & 8.9 & 32.8 & 1.1 & 1.8 \\
\hline 1942-1946 & 9.4 & 20.8 & 0.8 & 0.8 & 8.8 & 32.3 & 0.8 & 1.1 & - & - & - & - \\
\hline \multirow[t]{2}{*}{ 1937-1941 } & 9.9 & 34.0 & 0.7 & 1.3 & - & - & - & - & - & - & - & - \\
\hline & \multicolumn{4}{|c|}{ 2001-2005 } & \multicolumn{4}{|c|}{ 2006-2010 } & \multicolumn{4}{|c|}{ 2011-2015 } \\
\hline \multirow[t]{3}{*}{ Total population ${ }^{d}$} & \multicolumn{4}{|c|}{$1,822,603$} & \multicolumn{4}{|c|}{$1,842,393$} & \multicolumn{4}{|c|}{$1,815,152$} \\
\hline & \multicolumn{2}{|c|}{ Italian } & \multicolumn{2}{|c|}{ Foreign } & \multicolumn{2}{|c|}{ Italian } & \multicolumn{2}{|c|}{ Foreign } & Italian & \multicolumn{3}{|c|}{ Foreign } \\
\hline & 1,58 & 31,282 & 241,3 & & $1,512,537$ & & 329,856 & & $1,427,233$ & & 387, & 919 \\
\hline Total deaths ${ }^{\mathrm{d}}$ & & 22,2 & & & & 18,4 & 40 & & & 17,983 & & \\
\hline & Ital & ian & Forei & ign & & lian & Fore & ign & Italian & & Fore & eign \\
\hline & 21,1 & 13 & 1101 & & & 304 & 1136 & & 16,454 & & 1529 & \\
\hline
\end{tabular}

Notes: HDC: Highly Developed Countries; HMPC: High Migratory Pressure Countries

${ }^{a}$ Subjects in percentages, out of the total population: e.g., out of the total population (1,822,603 in 2001-2005) 86.8\% are Italians

${ }^{b}$ Deaths in percentages, out of the total deaths: e.g., out of the total deaths (22,214 in 2001-2005) 95.0\% occurred among Italians

${ }^{\mathrm{C}}$ Not applicable

${ }^{\mathrm{d}}$ In absolute numbers

Source: Authors' elaboration on Dynamic Rome Longitudinal Study cohort data and the Register of causes of death (ReNCaM) 


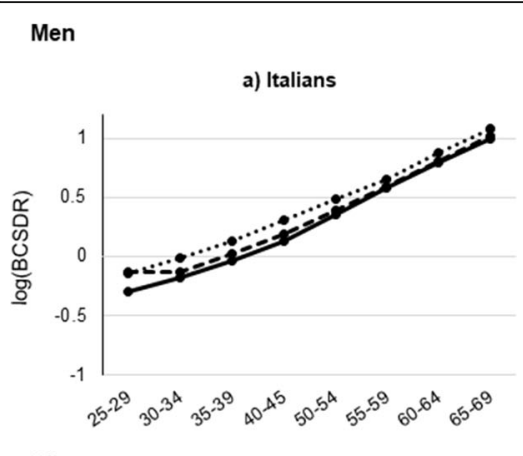

Women

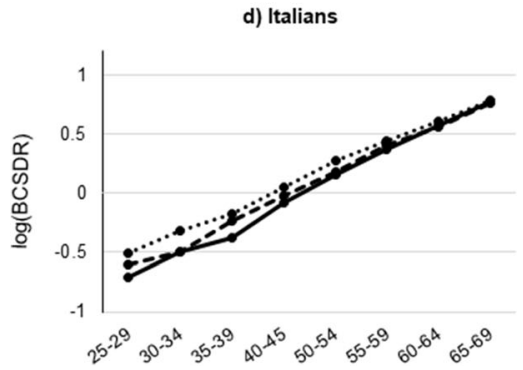

b) HMPC

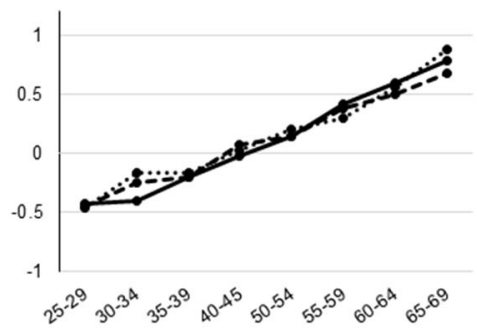

e) HMPC

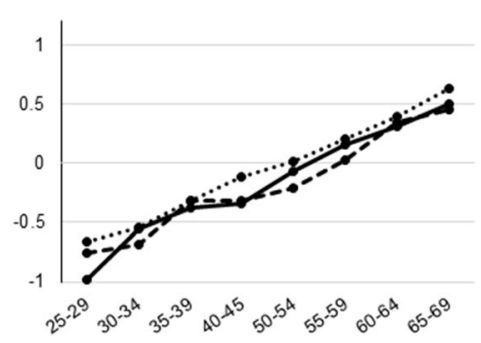

c) HDC

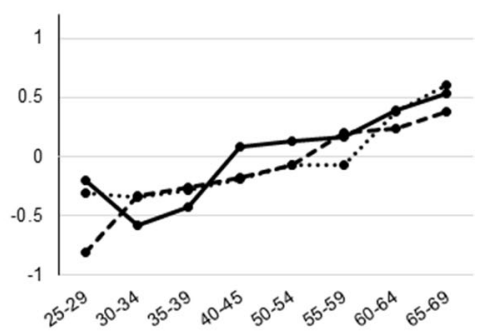

f) HDC

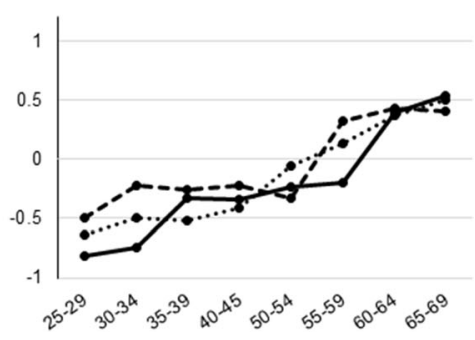

Fig. 1 Birth-cohort-specific death rates (BCSDR) by gender, migrant status, and time-period, 2001-2015. Notes: For the 2001-2005 time-period we selected the birth-cohorts from 1937 to 1976; for the 2006-2010 time-period the birth-cohorts from 1942 to 1981; for the 2011-2015 time-period the birth-cohorts from 1947 to 1986. In Appendix A, Fig. 1A shows birth-cohort-specific death rates (BCSDR) on a log-scale by gender, time-period, and migrant status. Source: Authors' elaboration on Dynamic Rome Longitudinal Study cohort data and the Register of causes of death (ReNCaM)

individuals of the same age, a decrease in the BCSDR can be detected among Italians, particularly among men and at young and adult ages, while such pattern is not clearly detected for migrants. Overall, women display lower BCSDR than men in all three time-periods analysed.

\section{Regression results for migrants as a heterogeneous group versus natives}

Table 2 shows the hazard ratios (HR) in gender-specific populations controlling for migrants from different areas of origin as a single heterogeneous group, timeperiod, and an interaction term between migrant status and the time-period in order to test whether the timeperiod effect on all-cause mortality differs between Italian and migrants. ${ }^{2}$ We found that the adjusted risk of dying for female $(\mathrm{HR}=0.61,95 \% \mathrm{CI} 0.56-0.66)$ and male $(\mathrm{HR}=0.49,95 \% \mathrm{CI} 0.45-0.53)$ migrants is lower compared to the risk for natives. Compared to the first time-period (2001-2005), results show lower mortality in the second (2006-2010: Women, $\mathrm{HR}=0.89,95 \% \mathrm{CI}$ 0.86-0.92 -- Men, HR $=0.84$, 95\% CI 0.81-0.86) and third time-period (2011-2015: Women, HR $=0.86$, 95\%

\footnotetext{
${ }^{2}$ In Appendix B, Table 1B shows gender-specific mortality HR for migrants versus Italians residing in Rome stratified by time-period. The likelihood ratio test shows that the model with the interaction term fits significantly better than the model without the interaction term for both genders $(p<0.05)$.
}

CI $0.83-0.89$-- Men, HR=0.77, 95\% CI 0.75-0.79) for both genders. In addition, from a further analysis that we do not show for sake of brevity, switching and choosing the 2006-2010 time-period as the reference category, we found that the difference in mortality between the third and the second time-period is smaller than that between the second and the first time-period. Specifically, among men the difference (between the third and the second time-period) is small ( $\mathrm{HR}=0.92$, 95\% CI $0.90-0.95, p$-value <0.001), while among women, although the difference is still detectable, it is slightly significant $(\mathrm{HR}=0.97,95 \%$ CI $0.94-1.00, p$ value 0.067$)$. This result might suggest a slowdown in mortality decrease.

As regards the interaction between migrant status and the time-period, the results suggest that in 2011-2015 the effect of time on mortality is less strong on migrant men than the average effect of time on Italians, while there are no differences in 2006-2010. Conversely, among migrant women, the effect of time on mortality is stronger in 2006-2010, without differences in the third time-period.

\section{Regression results by migrants' area of origin}

Figure 2 shows gender-specific hazard estimates by time-period and by area of origin. All migrant groups have lower mortality with respect to Italians (blue dot line) for both men and women, across age and across 
Table 2 Gender-specific mortality HR for migrants versus Italians residing in Rome, 2001-2015

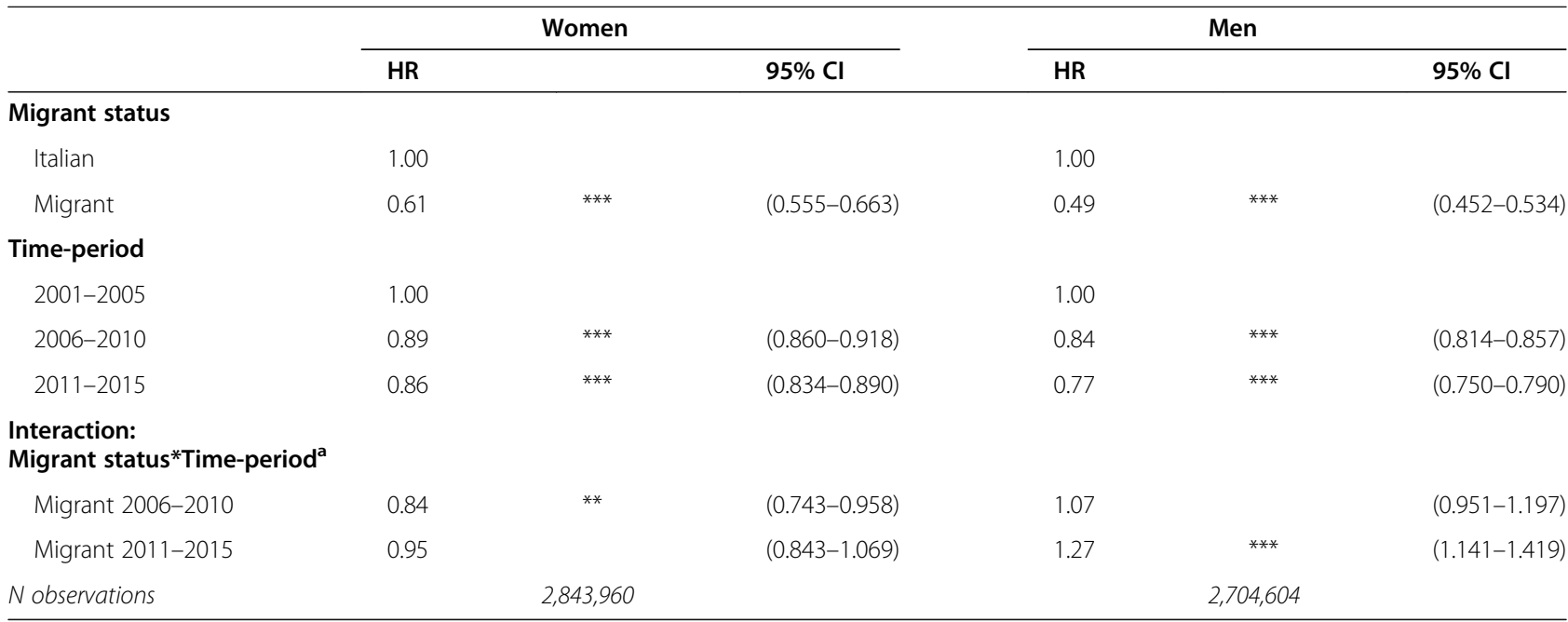

Notes: Parametric survival model with Gompertz baseline hazard and age as the time-scale

The asterisks indicate significance ${ }^{*} p<0.05,{ }^{* *} p<0.01,{ }^{* * *} p<0.001$

aLikelihood ratio test - Women: $p$-value $=0.026$; Men: $p$-value $=0.000$

Source: Authors' elaboration on Dynamic Rome Longitudinal Study cohort data and the Register of causes of death (ReNCaM)

time-period. The graph also displays changes over time in the risk of dying for the populations considered. Looking at the three time-periods separately, for male and female Italians, hazard curves suggest a lower risk of dying over time. Actually, from the first time-period to the third one, the blue dot line falls, suggesting an increase in survival probability. Conversely, the coloured solid lines, which represent migrant groups, get closer with time, showing a reduction in the mortality gap between Italians and migrants, in particular among

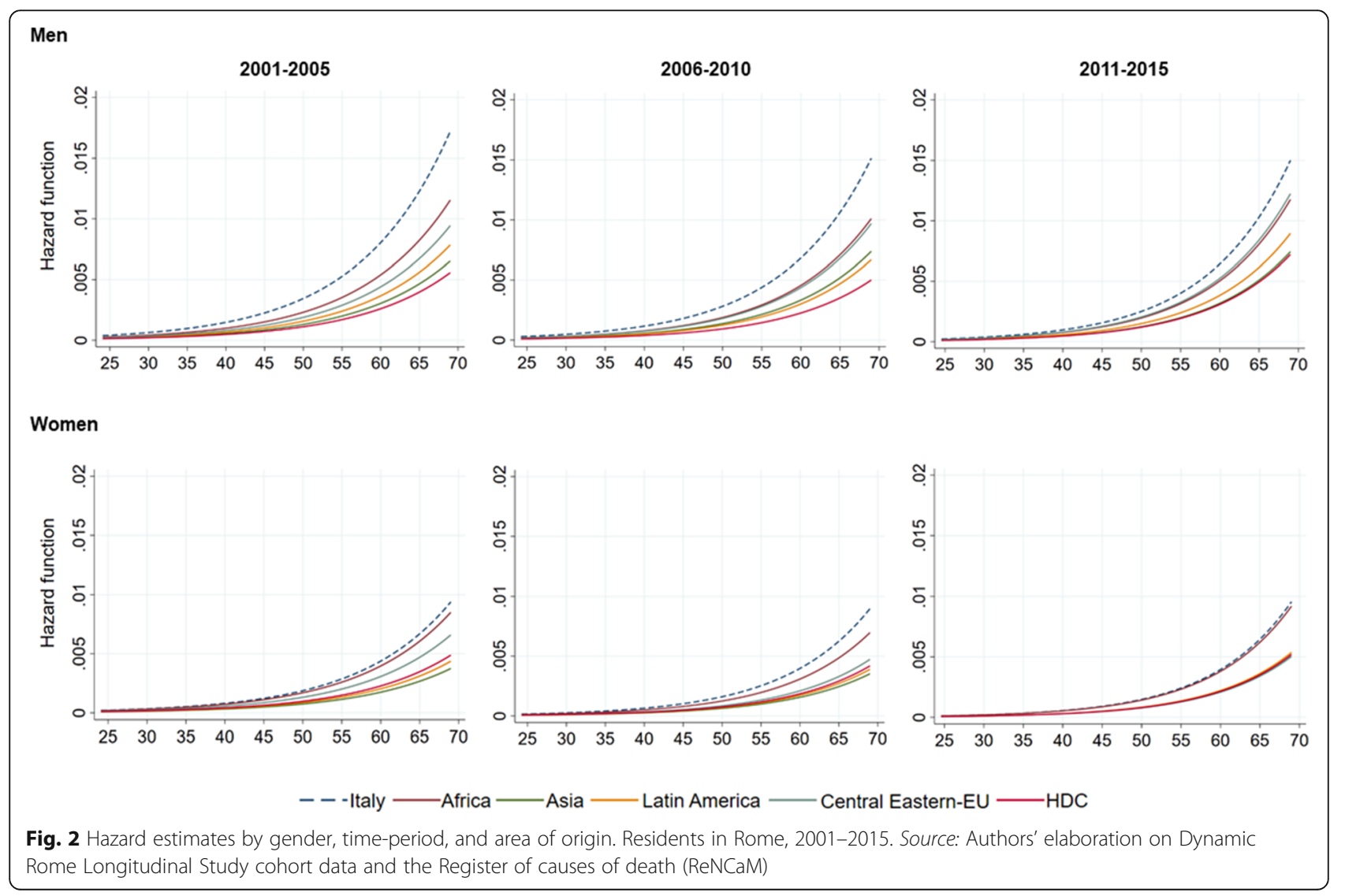


migrant men. In addition, for both men and women (except for African women) the mortality difference between Italians and migrant groups was always statistically significant (Table 3). Among women, the mortality pattern in the 2011-2015 time-period shows two clusters: Italians and Africans had a similar risk of dying (the hazard curves overlap); while Asians, Central Eastern Europeans, Latin America, and HDC had a mortality advantage.

Combining data for the different time-periods we examined gender-specific hazard ratios for each migrant group according to the area of origin. Mortality among women from Asia, Latin America, Central Eastern Europe and HDC was, respectively, 59\% $(\mathrm{HR}=0.41,95 \%$ CI $0.32-0.53), 52 \% \quad(\mathrm{HR}=0.48,95 \%$ CI $0.37-0.61), 27 \%(\mathrm{HR}=0.73,95 \%$ CI $0.58-0.90)$ and $48 \% \quad(\mathrm{HR}=0.52, \quad 95 \%$ CI $0.44-0.62)$ lower than Italians; while mortality among women from Africa was similar to mortality among Italian women $(\mathrm{HR}=$
0.91, 95\% CI 0.78-1.06). Mortality among men from Africa, Asia, Latin America, Central Eastern Europe and $\mathrm{HDC}$ was, respectively, 33\% $(\mathrm{HR}=0.67,95 \% \mathrm{CI}$ $0.59-0.76), 61 \%$ (HR $=0.39,95 \%$ CI $0.32-0.47), 54 \%$ $(\mathrm{HR}=0.46,95 \%$ CI $0.36-0.59), 44 \% \quad(\mathrm{HR}=0.56,95 \%$ CI $0.45-0.70)$ and $67 \%(\mathrm{HR}=0.33,95 \%$ CI $0.27-0.40)$ lower than their Italians counterparts. Compared to 2001-2005, in the second (2006-2010) and third (2011-2015) time-period, a lower risk of dying was observed for the whole population, regardless of gender, with some differences according to the area of origin. Among men, the interaction between the area of origin and time-period suggests that the effect of time on their death risk was less strong among Central Eastern Europeans in the 2011-2015 period and among migrants from HDC in the 2011-2015 period. Conversely, among women, the effect of time on mortality was stronger only among Central Eastern Europeans in the 2006-2010 and in the 2011-2015

Table 3 Gender-specific mortality HR for different migrant groups versus Italians residing in Rome, 2001-2015

\begin{tabular}{|c|c|c|c|c|c|c|}
\hline \multirow[b]{2}{*}{ Area of origin } & \multicolumn{3}{|c|}{ Women } & \multicolumn{3}{|c|}{ Men } \\
\hline & HR & & $95 \% \mathrm{Cl}$ & HR & & $95 \% \mathrm{Cl}$ \\
\hline Italy & 1.00 & & & 1.00 & & \\
\hline Africa & 0.91 & & $(0.780-1.058)$ & 0.67 & $* * *$ & $(0.594-0.764)$ \\
\hline Asia & 0.41 & $* * *$ & $(0.321-0.530)$ & 0.39 & $* * *$ & $(0.318-0.472)$ \\
\hline Latin America & 0.48 & $* * *$ & $(0.373-0.611)$ & 0.46 & $* * *$ & $(0.364-0.592)$ \\
\hline Central-Eastern Europe & 0.73 & $* *$ & $(0.582-0.903)$ & 0.56 & $* * *$ & $(0.452-0.703)$ \\
\hline $\mathrm{HDC}$ & 0.52 & $* * *$ & $(0.442-0.615)$ & 0.33 & $* * *$ & $(0.265-0.400)$ \\
\hline \multicolumn{7}{|l|}{ Time-period } \\
\hline 2001-2005 & 1.00 & & & 1.00 & & \\
\hline 2006-2010 & 0.89 & $* * *$ & $(0.860-0.918)$ & 0.84 & $* * *$ & $(0.814-0.857)$ \\
\hline 2011-2015 & 0.86 & $* * *$ & $(0.834-0.890)$ & 0.77 & $* * *$ & $(0.750-0.790)$ \\
\hline \multicolumn{7}{|l|}{$\begin{array}{l}\text { Interaction: } \\
\text { Area of origin*Time-period }{ }^{\mathrm{a}}\end{array}$} \\
\hline Africa 2006 & 0.85 & & $(0.675-1.083)$ & 0.99 & & $(0.822-1.193)$ \\
\hline Africa 2011 & 1.05 & & $(0.839-1.322)$ & 1.15 & & $(0.958-1.380)$ \\
\hline Asia 2006 & 0.95 & & $(0.679-1.335)$ & 1.26 & & $(0.977-1.622)$ \\
\hline Asia 2011 & 1.24 & & $(0.913-1.681)$ & 1.24 & & $(0.971-1.582)$ \\
\hline Latin America 2006 & 0.91 & & $(0.642-1.291)$ & 0.95 & & $(0.666-1.359)$ \\
\hline Latin America 2011 & 1.15 & & $(0.838-1.576)$ & 1.26 & & $(0.910-1.745)$ \\
\hline Central Eastern Europe 2006 & 0.73 & * & $(0.548-0.963)$ & 1.14 & & $(0.862-1.498)$ \\
\hline Central Eastern Europe 2011 & 0.71 & ** & $(0.546-0.913)$ & 1.39 & $* *$ & $(1.080-1.797)$ \\
\hline HDC 2006 & 0.89 & & $(0.696-1.146)$ & 1.01 & & $(0.753-1.368)$ \\
\hline HDC 2011 & 1.04 & & $(0.804-1.334)$ & 1.46 & $* *$ & $(1.096-1.944)$ \\
\hline Nobservations & & 3,960 & & & $2,704,604$ & \\
\hline
\end{tabular}

Notes: Parametric survival model with Gompertz baseline hazard and age as the time-scale

The asterisks indicate significance ${ }^{*} p<0.05,{ }^{* *} p<0.01,{ }^{* * *} p<0.001$

a Likelihood ratio test - Women: $p$-value $=0.044$; Men: $p$-value $=0.004$

In Appendix B, Table 2B shows gender-specific mortality HR for migrants' area of origin versus Italians residing in Rome stratified by time-period

Source: Authors' elaboration on Dynamic Rome Longitudinal Study cohort data and the Register of causes of death (ReNCaM) 
period, while there were no changes in the risk of dying over time, between Italians and all other migrant groups (Table 3$)^{3}$

\section{Discussion}

Using a population-based open cohort design, the present study investigates the association between migrant status and all-cause mortality among Rome residents from 2001 to 2015 by birth-cohort. By comparing three different time-periods, we also analyse changes in mortality patterns before and during the Great Recession.

In line with other international $[5,6,46-53]$ and national [38-42] studies, the findings confirm the first hypothesis on the migrant mortality advantage. Compared to the Italian-born population, migrants have significantly lower all-cause mortality, regardless of the area of origin, and for both genders; except for African women who register similar mortality patterns to Italian women. The migrant mortality advantage may result from two selection hypotheses. The first one, known as the healthy migrant effect $[46,54,55]$, suggests the selection of healthy individuals into migration. The second one, known as the salmon bias $[56,57]$, proposes the remigration of unhealthy individuals to their origin country, something particularly important among elderly migrants. However, the remigration of unhealthy individuals to their origin country is hard to test and few existing studies analyse this issue. Norredam et al. (2014) [58], for instance, found weak support for the remigration bias hypothesis in Denmark. Recently, in another study by Di Napoli et al. (2021) [59], which analyse the salmon bias effect hypothesis among migrants in Italy, the authors found that the salmon bias only partly explains the difference in mortality rates between migrants and non-migrants.

What is more, the data artefact and its reliability should be taken into account [5, 60-62]. We have delays in registration in municipal registries upon arrival or the final return to the origin country, which can lead to an additional underestimation of migrants' mortality. In a period of economic crisis, the increased mobility of migrants who may leave the host country to look for job opportunities in other countries or remigrate to their origin country will perhaps affect the data artefact more strongly [63]. Nevertheless, Wallace and Wilson (2021) [64], studying the Swedish context, found that the data artefact could explain some, but not all, of the mortality

\footnotetext{
${ }^{3}$ In Appendix B, Table 2B shows gender-specific mortality hazard ratios for different migrant groups versus Italians residing in Rome by time-period. The likelihood ratio test shows that the model with the interaction term fits significantly better than the model without the interaction term for both genders $(p<0.05)$.
}

advantage detected. This result demonstrates that such a pattern is real.

As expected, we found support for our second hypothesis about mortality changes over time. Overall, we found a lower risk of dying for both genders over time. This pattern reflects the general improvement detected in the last years, resulting in an increase in life expectancy $[65,66]$. In addition, whereas during the time period analysed, the Italian economic conjuncture was particularly negative, one would have expected a mortality increase (counter-cyclical effect). The observed pro-cyclical effects (meaning mortality goes up with economic expansions and down with contractions), which is counterintuitive, should be referred to the "Thomas effect" [67]. The explanation for this pattern is that some important determinants of ill health and death are correlated with economic activity. For example, for trafficking-related mortality, economic downturns reduce industrial and commercial traffic, as well as commuting and recreational driving. Furthermore, we must also consider that economic expansion also brings overtime hours and higher intensity work, leading to less time for sleep, physical activity, and social interactions. Atmospheric pollution, social isolation, and cigarette smoking also increase in times of economic growth and decrease in recessions [68-70].

Finally, our findings support the third hypothesis according to which the effect of the Great Recession might be captured during the third period. This is in line with a recent study by Egidi and Demuru (2016) [31], where the authors studied the relationship between the economic crisis and mortality trends at the national level, revealing that the Great Recession had modified and slowed down mortality trends, in particular mortality improvements.

The effect of time detected for the whole population changes according to gender and area of origin. Among men, the mortality improvement was less strong for Central Eastern Europeans in the 2011-2015 timeperiod, and for migrants from HDC in the 2011-2015 time-period. This finding could be related to the often poor socioeconomic conditions in which migrants live $[71,72]$ and to the process of acculturation that may induce scarce opportunities to adopt healthy habits and lifestyles $[73,74]$. It could also be explained by the economic downturn compounding precarious employment conditions and low socioeconomic status. Certainly, there is evidence that migrant health worsens with longer residence in the host country [44, 75-77]. However, in the absence of information about the length of stay, we cannot confirm this hypothesis. Conversely, among women, we found that mortality improvements were stronger only among Central Eastern Europeans both in the second (2006-2010) and the third (2011-2015) 
time-period with respect to the first (2001-2005). No difference was observed for other migrant groups. This trend could be related to EU membership for Poland and the Czech Republic in 2004 and for Romania and Bulgaria in 2007. This modified the composition of migration flows to Italy, helped along by strong Italian demand for domestic workers and caregivers [77, 78]. Finally, further studies are needed to investigate the socio-structural drivers of the differences in mortality that emerged in the analysis. As argued by Hossin (2020) [79], these differences are linked to a wide range of premigratory and postmigratory vulnerabilities that mutually intersect.

This study is not without limitations. We could not account for some important mortality risk factors. As previously mentioned, migrants' length of stay in the host country is an important confounder. Several studies conducted in France [80], Canada [81], Belgium [73], and Norway [74], have shown an increase in migrant mortality with an increase in the length of stay.

In addition, our study did not consider socioeconomic variables, such as income, education, or even the reason for migration, which can influence the outcome and could have helped to explain the complex relationship between migrant status and mortality [82-85]. Furthermore, since the cohort is based on the Municipal Register of Rome, we included only residents, which means only regular migrants, while migrants without residence permits, who represent a particularly vulnerable population, were not included. Finally, the use of data from the Municipality of Rome might affect the external validity of the results because it is considered a part of the immigrant population residing in Italy. However, as regards the composition of migrantion flows, the distribution of the migrant population in Rome and in Italy is quite similar. In both cases, Romanians are the first community (36\%), and about $50 \%$ of migrants come from Eastern Europe. The major differences concern migrants from the Philippines and Bangladesh who are over-represented in Rome and this might limit the external validity of the results [37].

If there are drawbacks this study also has, though, important strengths. First, by using a longitudinal approach with open cohort data we were able to enrol all new entries during the follow-up, reflecting the great dynamism of the migrant population. Second, by linking the Municipal Register of Rome to the Register of Causes of Death we computed personyears, allowing us to obtain the person-time at risk and to estimate accurately mortality rates. Finally, using age as the time-scale gives more accurate results because it puts similar subjects in the risk set together and allows a completely non-parametric age effect. Furthermore, each individual contributes to the death risk only in the age interval in which he/she is exposed to the risk of experiencing the event.

Our findings are relevant for contemporary health systems because, for the first time, Italy has to deal with a significant migrant population. Even if the study is context-specific, our analyses rely on the Municipality of Rome which has the highest number of migrants in Italy and, therefore, represents a relevant and useful context for studying this issue, and one useful for health policy makers thinking of migrant mortality trends. Moreover, by analysing a period over 15 years, from 2001 to 2015, this work helps to better understand mortality trends by birth-cohort and to provide insights into the mortality patterns during the Great Recession.

Given the relevance of international migrations all over Europe, the importance of studying and exploring migrants' health is becoming increasingly evident. This is especially true for the implementation of targeted policies addressing migrants' integration. The deterioration in migrant health and the gradual weakening of their mortality advantage is likely to become a public health issue with important consequences for the healthcare system of all European countries.

Further researches with a longer follow-up and analyses focused on causes of death would be needed for a better description and explanation of mortality differential patterns observed between migrants and nonmigrants.

\section{Abbreviations}

BCSDR: Birth-Cohort-Specific Death Rates; Cl: Confidence Interval: HDC: Highly Developed Countries; HMPC: High Migratory Pressure Countries; HR: Hazard Ratios; IN-liMeS: Italian Network of Longitudinal Metropolitan studies; ReNCaM: Register of the Causes of Death

\section{Supplementary Information}

The online version contains supplementary material available at https://doi. org/10.1186/s12889-021-12176-8.

Additional file 1.

Acknowledgements

Not applicable.

\section{Authors' contributions}

Conception of the work: L.C., N.A., E.T., C.G.; design of the work: E.T., L.C., N.A., C.M.; acquisition of data: C.M., E.T.; analysis of data: E.T.; interpretation of data: L.C., E.T., C.M., C.G.; E.T. wrote the main manuscript text; All authors reviewed the manuscript. The authors read and approved the final manuscript.

\section{Funding}

None.

\section{Availability of data and materials}

The datasets generated, used and/or analysed during the current study are not publicly available due to stringent legal restrictions regarding the privacy policy on personal information in Italy (national legislative decree on privacy policy n. 196/30 June 2003) and ethical reasons. 


\section{Declarations}

\section{Ethics approval and consent to participate}

Ethical approval retrospective studies: the IN-LiMeS is part of the Italian National Statistical Program and was approved by the Italian Data Protection Authority. The authors obtained administrative permission from the Lazio Region Committee (Council decision No 152. Dated 01st April 2014) to access and analyse data of the regional health information systems for epidemiological purposes. All methods, including the record linkage procedures, data collection, and analyses, were completely anonymised, de-identified, and analysed in aggregate form for statistical purposes and performed following the relevant guidelines and regulations from the Italian Data Protection Authority. Therefore, no consent to participate was required.

\section{Consent for publication}

Not applicable.

\section{Competing interests}

The authors declare that they have no competing interests.

\section{Author details}

${ }^{1}$ University of Milano-Bicocca, Milan, Italy. ${ }^{2}$ Department of Epidemiology, Lazio Regional Health Service, Via Cristoforo Colombo, 112, 00147 Rome, Italy. ${ }^{3}$ Sapienza University of Rome, Rome, Italy.

\section{Received: 29 March 2021 Accepted: 3 November 2021}

Published online: 17 November 2021

\section{References}

1. Mesrine A. Les différences de mortalité par milieu social restent fortes. In: Données sociales: la société française. Paris: Insee; 1999. p. 228-35.

2. Marinacci C, Spadea T, Biggeri A, Demaria M, Caiazzo A, Costa G. The role of individual and contextual socioeconomic circumstances on mortality: analysis of time variations in a city of north West Italy. J Epidemiol Community Health. 2004;58(3):199-207. https://doi.org/10.1136/jech.2003. 014928.

3. Case A, Paxson C. Sex differences in morbidity and mortality. Demography. 2005;42(2):189-214. https://doi.org/10.1353/dem.2005.0011.

4. Schünemann J, Strulik H, Trimborn T. The gender gap in mortality: how much is explained by behavior? J Health Econ. 2017;54:79-90. https://doi. org/10.1016/j.jhealeco.2017.04.002.

5. Wallace M, Kulu H. Low immigrant mortality in England and Wales: a data artefact. Soc Sci Med. 2014;120:100-9. https://doi.org/10.1016/j.socscimed.2 014.08.032.

6. Wallace M, Kulu H. Mortality among immigrants in England and Wales by major causes of death, 1971-2012: a longitudinal analysis of register-based data. Soc Sci Med. 2015;147:209-21. https://doi.org/10.1016/j.socscimed.201 5.10 .060 .

7. Caselli G, Loi S, Strozza S. Chapter 13: migration, health and mortality in Italy: an unfinished story. In: Trovato F, editor. Migration, health and survival. Cheltenham: Edward Elgar Publishing; 2017. p. 234-57. https://doi.org/1 0.4337/9781785365973.00018.

8. Consob: Commissione Nazionale per le Società e la Borsa. https://www. consob.it/web/investor-education/le-crisi-finanziarie\#crisi_2007. Accessed 20 Jul 2021.

9. Istat: Istituto Nazionale di Statistica. Rapporto annuale 2016. La situazione del Paese (2016). https://www.istat.it/it/files//2016/05/Ra2016.pdf. Accessed 20 Jul 2021

10. Kentikelenis A, Karanikolos M, Reeves A, McKee M, Stuckler D. Greece's health crisis: from austerity to denialism. Lancet. 2014;383(9918):745-53. https://doi.org/10.1016/50140-6736(13)62291-6.

11. Regidor E, Vallejo F, Granados JAT, Viciana-Fernández FJ, de la Fuente L, Barrio G. Mortality decrease according to socioeconomic groups during the economic crisis in Spain: a cohort study of 36 million people. Lancet. 2016; 388(10060):2642-52. https://doi.org/10.1016/S0140-6736(16)30446-9.

12. Gerdtham UG, Rhum CJ. Deaths rise in good economic times: evidence from the OECD. Econ Hum Biol. 2006;4(3):298-316. https://doi.org/10.1016/j. ehb.2006.04.001

13. Karanikolos M, Mladovsky P, Cylus J, Thomson S, Basu S, Stuckler D, et al. Financial crisis, austerity and health in Europe. Lancet. 2013;381(9874):132331. https://doi.org/10.1016/S0140-6736(13)60102-6.
14. Simou E, Koutsogeorgou E. Effects of the economic crisis on health and healthcare in Greece in the literature from 2009 to 2013: a systematic review. Health Pol. 2013;115(2-3):111-9. https://doi.org/10.1016/j.healthpol.2 014.02.002.

15. Mattei G, Ferrari S, Pingani L, Rigatelli M. Short-term effects of the 2008 great recession on the health of the Italian population: an ecological study. Soc Psychiatry Psychiatr Epidemiol. 2014;49(6):851-8. https://doi.org/10.1 007/s00127-014-0818-z.

16. Granados JAT, Rodriguez JM. Health, economic crisis and austerity: a comparison of Greece. Finland Icel Health Pol. 2015;119(7):941-53. https:// doi.org/10.1016/j.healthpol.2015.04.009.

17. Ruggeri M, Tomassi S. The impact of economic crisis on mental and physical health in Italy. Clin Res. 2017;14(02):103-10.

18. Strumpf EC, Charters TJ, Harper S, Nandi A. Did the great recession affect mortality rates in the metropolitan United States? Effects on mortality by age, gender and cause of death. Soc Sci Med. 2017;189:11-6. https://doi. org/10.1016/j.socscimed.2017.07.016.

19. Nuemayer E. Recession lower (some) mortality rates: evidence from Germany. Soc Sci Med. 2004;58(6):1037-47. https://doi.org/10.1016/S02779536(03)00276-4.

20. Granados JAT. Increasing mortality during the expansions of the US economy, 1900-1996. Int J Epidemiol. 2005;34(6):1194-202. https://doi.org/1 0.1093/ije/dyi141.

21. Rhum CJ. A healthy economy can break your heart. Demography. 2007; 44(4):829-48. https://doi.org/10.1007/BF03208384.

22. Sullivan $\mathrm{D}$, von Wachter T. Job displacement and mortality: an analysis using administrative data. Q J Econ. 2009;124(3):1265-306. https://doi.org/1 0.1162/qjec.2009.124.3.1265.

23. Granados JAT, Dieu Roux AV. Life and death during the great depression. Proc Natl Acad Sci U S A. 2009;106(41):17290-5. https://doi.org/10.1073/pna S.0904491106.

24. Granados JAT. Economic growth and health progress in England and Wales: 160 years of a changing relation. Soc Sci Med. 2012;74(5):688-95. https:// doi.org/10.1016/j.socscimed.2011.11.019.

25. de la Fuente VS, Camino López MA, González IF, González Alcántara OJ, Ritzel DO. The impact of the economic crisis on occupational injuries. J Saf Res. 2014;48:77-85. https://doi.org/10.1016/j.jsr.2013.12.007.

26. Rolden HJA, van Bodegom D, van den Hout WB, Westendorp RGJ. Old age mortality and macroeconomic cycles. J Epidemiol Community Health. 2014; 68(1):44-50. https://doi.org/10.1136/jech-2013-202544.

27. Haaland VF, Telle K. Pro-cyclical mortality across socioeconomic groups and health status. J Health Econ. 2015:39:248-58. https://doi.org/10.1016/j.jhea leco.2014.08.005.

28. Stevens $A H$, Miller DL, Page ME, Filipski M. The best of times, the worst of times: understanding pro-cyclical mortality. Am Econ J Econ Policy. 2015; 7(4):279-311. https://doi.org/10.1257/pol.20130057.

29. Buchmueller TC, Grignon M, Jusot F, Perronnin M. Unemployment and mortality in France. Dept Econ McMaster Univ. 2007. https://ba sepub.dauphine.fr/handle/123456789/7024:1982-2002 Accessed 15 Jan 2019.

30. Burgard SA, Brand JE, House JS. Perceived job insecurity and worker health in the United States. Soc Sci Med. 2009;69(5):777-85. https://doi.org/10.101 6/.j.socscimed.2009.06.029.

31. Egidi V, Demuru E, Crise s e m. In: Golaz V, Lefèvre C, Véron J, editors. La crise dix ans après. Quels effets sur la conjoncture démographique des pays d'Europe du Sud. Paris : Ined: Documents de travail, 239; 2018. p. 74-5.

32. Boyd M. At a disadvantage: the occupational attainments of foreign born women in Canada. Int Migr Rev. 2014;18(4):1091-119. https://doi.org/10.11 77/019791838401800410

33. Marmot MG, Adelstein AM, Bulusu L. Lessons from the study of immigrant mortality. Lancet. 1984;1(8392):1455-7. https://doi.org/10.1016/s0140-673 6(84)91943-3.

34. Razum O, Twardella D. Time travel with Oliver twist-towards an explanation for a paradoxically low mortality among recent immigrants. Tropical Med Int Health. 2002;7(1):4-10. https://doi.org/10.1046/j.1365-3156.2002.00833.x.

35. Norredam M, Olsbjerg M, Petersen JH, Juel K, Krasnik A. Inequalities in mortality among refugees and immigrants compared to native Danes - a historical prospective cohort study. BMC Public Health. 2012;12(1):1-9. https://doi.org/10.1186/1471-2458-12-757.

36. Donato KM, Piya B, Jacobs A. The double disadvantage reconsidered: gender, immigration, marital status, and global labor force participation in 
the 21st century. Int Migr Rev. 2014;48(Suppl 1):335-76. https://doi.org/1 $0.1111 /$ imre. 12142

37. Istat: Istituto Nazionale di Statistica. Demografia in Cifre. 2020. http://demo istat.it/. Accessed 18 Nov 2020

38. Martini A, Chellini E, Sala A. Mortality in immigrants in Tuscany. Epidemiol Prev. 2011;35(5-6):275-81.

39. Morandi I, Caracci G, De Giacomi G, Carletti P, Martinelli D, Martinelli D, Fortunato F. La salute della popolazione immigrata: il monitoraggio da parte dei Sistemi Sanitari Regionali. 2013. https:/www2.immigrazione. regione.toscana.it/sites/default/files/La_salute_della_popolazione_immigra ta_il_monitoraggio_da_parte_dei_Sistemi_Sanitari_Regionali.pdf. Accessed 2 Mar 2018.

40. Fedeli U, Ferroni E, Pigato M, Avossa F, Saugo M. Causes of mortality across different immigrant groups in northeastern Italy. PeerJ. 2015;69:1-13. https://doi.org/10.7717/peerj.975

41. Caranci N, Di Girolamo C, Rossi PG, et al. Cohort profile: the Italian network of longitudinal metropolitan studies (IN-LiMeS), a multicentre cohort for socioeconomic inequalities in health monitoring. BMJ Open. 2018;8(4): e020572. https://doi.org/10.1136/bmjopen-2017-020572.

42. Petrelli A, Di Napoli A, Agabiti N, et al. Immigrants' health and socioeconomic inequalities of overall population residing in Italy evaluated through the Italian network of Longitudinal Metropolitan Studies. Epidemiol Prev. 2019:43((5-6) Suppl 1):1-80.

43. Conti C, Strozza S. Gli immigrati stranieri e la capitale: condizioni di vita e atteggiamenti dei filippini, marocchini, peruviani e romeni a Roma, vol. 406. FrancoAngeli: Milano; 2006.

44. Trappolini E, Marino C, Agabiti N, Giudici C, Davoli M, Cacciani L. Disparities in emergency department use between Italians and migrants residing in Rome, Italy: the Rome dynamic longitudinal study from 2005 to 2015. BMC Public Health. 2020;20(1):1-14. https://doi.org/10.1186/s12 889-020-09280-6.

45. Korn EL, Graubard BI, Midhune D. Time-to-event analysis of longitudinal follow-up of a survey: choice of the time-scale. Am J Epidemiol. 1997;145(1): 72-80. https://doi.org/10.1093/oxfordjournals.aje.a009034.

46. McDonald JT, Kennedy S. Insights into the 'healthy immigrant effect': health status and health service use of immigrants to Canada. Soc Sci Med. 2004; 59(8):1613-27. https://doi.org/10.1016/j.socscimed.2004.02.004.

47. Ronellenfitsch U, Kyobutungi C, Becher H, Razum O. All-cause and cardiovascular mortality among ethnic German immigrants from the former Soviet Union: a cohort study. BMC Public Health. 2006;6(1):1-12. https://doi. org/10.1186/1471-2458-6-16.

48. Hajat A, Blakely T, Dayal S, Jatrana S. Do New Zealand's immigrants have a mortality advantage? Evidence from the New Zealand census-mortality study. Ethnic Health. 2010;15(5):531-47. https://doi.org/10.1080/13557858.2 010.496479

49. Blue L, Fenelon A. Explaining low mortality among US immigrants relative to native-born Americans: the role of smoking. Int J Epidemiol. 2011;40(3): 786-93. https://doi.org/10.1093/ije/dyr011.

50. Boulogne R, Jougla E, Breem Y, Kunst AE, Rey G. Mortality differences between the foreign-born and locally-born population in France (2004-2007). Soc Sci Med. 2012;74(8):1213-23. https://doi.org/10.1016/j.socscimed.2012.01.002.

51. Choi SH. Testing healthy immigrant effects among late life immigrants in the United States: using multiple indicators. J Aging Health. 2012;24(3):475506. https://doi.org/10.1177/0898264311425596.

52. Moncho J, Pereyra-Zamora P, Nolasco A, Tamayo-Fonseca N, Melchor I, Macia L. Trends and disparities in mortality among Spanish-born and foreign-born populations residing in Spain, 1999-2008. J Immigr Minor Health. 2015;17(5):1374-84. https://doi.org/10.1007/s10903-0140081-0.

53. Aldridge RW, Nellums LB, Bartlett S, Barr AL, Patel P, Burns R, et al. Global patterns of mortality in international migrants: a systematic review and meta-analysis. Lancet. 2018;392(10164):2553-66. https://doi.org/10.1016/S014 0-6736(18)32781-8

54. Razum O, Zeeb H, Rohrmann S. The 'healthy migrant effect'-not merely a fallacy of inaccurate denominator figures. Int J Epidemiol. 2000;29(1):191-2. https://doi.org/10.1093/ije/29.1.191

55. Ullmann SH, Goldman N, Massey DS. Healthier before they migrate, less healthy when they return? The health of returned migrants in Mexico. Soc Sci Med. 2011;73(3):421-8. https://doi.org/10.1016/j.socscimed.2011.05.037.

56. Abraído-Lanza AF, Dohrenwend BP, Ng-Mak DS, Turner JB. The Latino mortality paradox: a test of the 'salmon bias' and healthy migrant hypotheses. Am J Public Health. 1999;89(10):1543-8. https://doi.org/10.21 05/A.PH.89.10.1543.

57. Razum O. Commentary: of salmon and time travellers-musing on the mystery of migrant mortality. Int J Epidemiol. 2006;35(4):919-21. https://doi. org/10.1093/ije/dyl143.

58. Norredam M, Hansen OH, Petersen JH, Kunst AE, Kristiansen M, Krasnik A, et al. Remigration of migrants with severe disease: myth or reality? A register-based cohort study. Eur J of Public Health. 2014;25(1):84-9. https:// doi.org/10.1093/eurpub/cku138.

59. Di Napoli A, Rossi A, Alicandro G, Ventura M, Frova L, Petrelli A. Salmon bias effect as hypothesis of the lower mortality rates among immigrants in Italy. Sci Rep. 2021;11(1):8033. https://doi.org/10.1038/s41 598-021-87522-2.

60. Weitoft GR, Gullberg A, Hjern A, Rosén M. Mortality statistics in immigrant research: method for adjusting underestimation of mortality. Int J Epidemiol. 1999;28(4):756-63. https://doi.org/10.1093/ije/28.4.756.

61. Kibele E, Scholz R, Shkolnikov VM. Low migrant mortality in Germany for men aged 65 and older: fact or artifact. Eur J Epidemiol. 2008;23(6):389-93. https://doi.org/10.1007/s10654-008-9247-1.

62. Monti A, Drefahl S, Mussino E, Härkönen J. Over-coverage in population registers leads to bias in demographic estimates. Popul Stud. 2019;74(3):119. https://doi.org/10.1080/00324728.2019.1683219.

63. Fedeli U, Cestari L, Ferroni E, Avossa F, Saugo M, Modesti PA. Ethnic inequalities in acute myocardial infarction hospitalization rates among young and middleaged adults in northern Italy: high risk for south Asians. Intern Emerg Med. 2018;13(2):177-82. https:/doi.org/10.1007/s11739-017-1631-y.

64. Wallace M, Wilson B. Age variations and population over-coverage: is low mortality among migrants merely a data artefact. Popul Stud. 2021:1-18. https://doi.org/10.1080/00324728.2021.1877331.

65. Felice E, Andreu JP, D'Ippoliti C. GDP and life expectancy in Italy and Spain over the long run: a time-series approach. DemRes. 2016;35:813-66. https:// doi.org/10.4054/DemRes.2016.35.28.

66. Passarino G, De Rango F, Montesanto A. Human longevity: genetics or lifestyle? It takes two to tango. Immun Ageing. 2016;13(1):12-7. https://doi. org/10.1186/s12979-016-0066-z.

67. Granados JAT, lonides EL. Population health and the economy: mortality and the great recession in Europe. Health Econ. 2017;26(12):e219-35. https://doi.org/10.1002/hec.3495.

68. Sterling P, Eyer J. Biological basis of stress-related mortality. Soc Sci MedMed Psyc. 1981;15(1):3-42. https://doi.org/10.1016/0271-5384(81)90061-2.

69. Davis ME, Laden F, Hart JE, Garshick E, Smith TJ. Economic activity and trends in ambient air pollution. Environ Health Perspect. 2010;118(5):614-9. https://doi.org/10.1289/ehp.0901145.

70. Heutel G, Ruhm CJ. Air pollution and procyclical mortality. Journal of the Association of Environmental and Resource Economists. 2016;3(3):667-706 https://doi.org/10.1086/686251.

71. Malmusi D, Borrell C, Benach J. Migration-related health inequalities: showing the complex interactions between gender, social class and place of origin. Soc Sci Med. 2010;71(9):1610-9. https://doi.org/10.1016/j. socscimed.2010.07.043

72. Gimeno-Feliu LA, Calderón-Larrañaga A, Díaz E, Laguna-Berna C, PobladorPlou B, Coscollar-Santaliestra C, et al. The definition of immigrant status matters: impact of nationality, country of origin, and length of stay in host country on mortality estimates. BMC Public Health. 2019;19(1):247. https:// doi.org/10.1186/s12889-019-6555-1.

73. Vandenheede H, Willaert D, De Grande H, Simoens S, Vanroelen C. Mortality in adult immigrants in the 2000s in Belgium: a test of the 'healthy-migrant'and the 'migration-as-rapid-health-transition'hypotheses. Tropical Med Int Health. 2015;20(12):1832-45. https://doi.org/10.1111/ tmi.12610.

74. Syse A, Strand BH, Naess O, Steingrímsdóttir ÓA, Kumar BN. Differences in all-cause mortality: a comparison between immigrants and the host population in Norway 1990-2012. DemRes. 2016;34:615-56. https://doi.org/1 0.4054/DemRes.2016.34.22.

75. Hill TD, Angel JL, Balistreri KS, Herrera AP. Immigrant status and cognitive functioning in late life: an examination of gender variations in the healthy immigrant effect. Soc Sci Med. 2012;75(12):2076-84. https://doi.org/10.1016/ j.socscimed.2012.04.005.

76. Loi S, Hale JM. Migrant health convergence and the role of material deprivation. DemRes. 2019:40(32):933-62. https://doi.org/10.4054/DemRes.2 019.40.32. 
77. Trappolini E, Giudici C. Gendering health differences between nonmigrants and migrants by duration of stay in Italy. DemRes. 2021;45(7):221-58. https://doi.org/10.4054/DemRes.2021.45.7.

78. Bettin G, Cela E. The evolution of migration flows in Europe and Italy. Economia Marche J Appl Econ. 2014;33(1):37-63.

79. Hossin MZ. International migration and health: it is time to go beyond conventional theoretical frameworks. BMJ Glob Health. 2020;5(2):e001938. https://doi.org/10.1136/bmjgh-2019-001938.

80. Wallace M, Khlat M, Guillot M. Mortality advantage among migrants according to duration of stay in France, 2004-2014. BMC Public Health. 2019;19(1):1-9. https://doi.org/10.1186/s12889-019-6652-1.

81. Omariba DWR, Ng E, Vissandjée B. Differences between immigrants at various durations of residence and host population in all-cause mortality, Canada 1991-2006. Popul Stud. 2014;68(3):339-57. https://doi.org/10.1080/ 00324728.2014 .915050

82. Trewin CB, Strand BH, Weedon-Fekjær H, Ursin G. Changing patterns of breast cancer incidence and mortality by education level over four decades in Norway, 1971-2009. Eur J Pub Health. 2017;27(1):160-6. https://doi.org/1 0.1093/eurpub/ckw148.

83. O'Rand AM, Lynch SM. Socioeconomic status, health, and mortality in aging populations. In: Future directions for the demography of aging: proceedings of a workshop. Washington DC: National Academies Press; 2018. p. 67-95.

84. Montez JK, Zajacova A, Hayward MD, Woolf SH, Chapman D, Beckfield J. Educational disparities in adult mortality across US states: how do they differ, and have they changed since the mid-1980s. Demography. 2019; 56(2):621-44. https://doi.org/10.1007/s13524-018-0750-z.

85. Oksuzyan A, Mussino E, Drefahl S. Sex differences in mortality in migrants and the Swedish-born population: is there a double survival advantage for immigrant women. Int J Public Health. 2019;64(3):377-86. https://doi.org/1 0.1007/s00038-019-01208-1.

\section{Publisher's Note}

Springer Nature remains neutral with regard to jurisdictional claims in published maps and institutional affiliations.

Ready to submit your research? Choose BMC and benefit from:

- fast, convenient online submission

- thorough peer review by experienced researchers in your field

- rapid publication on acceptance

- support for research data, including large and complex data types

- gold Open Access which fosters wider collaboration and increased citations

- maximum visibility for your research: over $100 \mathrm{M}$ website views per year

At $\mathrm{BMC}$, research is always in progress.

Learn more biomedcentral.com/submissions 